\title{
A new species of Catenes Distant from South America (Hemiptera, Heteroptera, Lygaeoidea, Rhyparochromidae)
}

\author{
Pablo Matías Dellapé*, 1 and María Cecilia Melo $^{2}$ \\ ${ }^{1}$ División Entomología, Facultad de Ciencias Naturales y Museo, Universidad Nacional de La Plata (UNLP), Paseo del Bosque s/n, \\ 1900 La Plata, Argentina \\ 2 Departamento Sistemática, Instituto de Limnología "R.A. Ringuelet” (ILPLA), UNLP-CONICET, Buenos Aires, Argentina
}

\begin{abstract}
Received 7 February 2008

Accepted 25 April 2008

Published 5 November 2008

\section{Key Words}

The genus Catenes includes two species, C. porrectus Distant from Guatemala and Panama, and C. spiculus Slater and Baranowski from Dominican Republic. Catenes australis sp. n. is described from Bolivia, Brazil, Ecuador, and Peru. Colour figure, and male genitalia are illustrated. A key for the three known species of Catenes, and a map with the geographic distribution of the genus is given. The type material is deposited in the entomological collection of the Museo de La Plata (Argentina).
\end{abstract}

Catenes australis

Myodochini

Neotropical Region

\section{Introduction}

The genus Catenes was erected by Distant (1893) to include C. porrectus from Guatemala and Panama; Slater \& Baranowski (1994) described a second species, C. spiculus, from Dominican Republic. In this contribution we described a third species, which extends the geographic distribution of this genus to South America. A photograph of dorsal habitus, and figures of male genitalia are given. A key to separate the species of the genus is presented.

The holotype and paratypes are deposited in the entomological collection of the Museo de La Plata (Argentina). Additional material was loaned by the following institutions: Museo Argentino de Ciencias Naturales, Argentina (MACN); Florida Museum of Natural History, University of Florida, Gainesville, USA (FSMC); and Museu de Zoologia, Universidade de São Paulo, São Paulo, Brazil (MZSP).

\section{Results}

\section{Catenes australis sp. n.}

Figures 1-7; Table 1

Type material. Holotype: 1 male, PERU, Cusco, Pagoreni $\left(72^{\circ} 54^{\prime} 07^{\prime \prime} \mathrm{W}-11^{\circ} 42^{\prime} 07^{\prime \prime} \mathrm{S}\right)$, luz, VII-[20]04, J. Williams (MLP). Paratypes: 3 males 2 females, PERU, Cusco, San Martin 2 - Base Pluspetrol $\left(72^{\circ} 46^{\prime} 53^{\prime \prime} \mathrm{W}-11^{\circ} 46^{\prime} 17^{\prime \prime} \mathrm{S}\right.$ ), luz, II-[20]06, J. Williams (MLP).

Additional material. ECUADOR: 1 female, Prov. Napo, vic. Puerto Misahuali, 1650-1900 ft, 6/19-IX-1998, J. E. Eger coll., 1 122'4,2" S$77^{\circ} 39^{\prime} 49,2^{\prime \prime} \mathrm{W}$, on Mercury vapor \& Ultraviolet lights (FSMC); 1 male, same data, on Fish carrion baited butterfly trap, $H$. nr cincticornis det. R. M. Baranowski (FSMC). BRAZIL: 1 male, Faz. Nova Orlandia, Jataí, Go-Brasil, I-[1]964- Martinez, Morgante \& Silva (MZSP). BOLIVIA: 1 male, Chaparé (Yungas), I-[19]49, Bridarolli (MACN).

Diagnosis. Large, over $8 \mathrm{~mm}$. Scapus dark, surpassing about $1 / 2$ apex of head. Rostrum short, slightly surpassing procoxae. Meso- and metatibiae with a subbasal brown band.

\footnotetext{
* Corresponding author, e-mail: pdellape@fcnym.unlp.edu.ar
} 


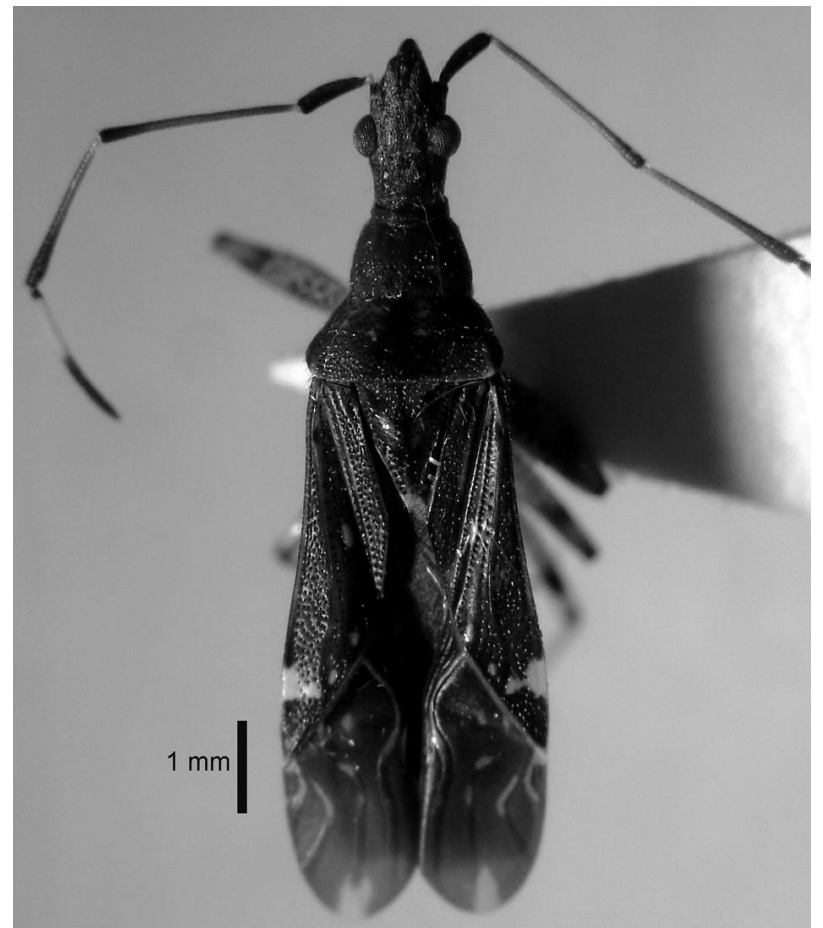

Figure 1. Catenes australis sp. n.; habitus of male.

Description. Holotype, male.

Body. Elongate, large and pruinose. Head: porrect, black, with abundant short decumbent silver setae. Ver- tex flattened. Clypeus long. Eyes rounded, not surpassing margins of head laterally. Ocelli small, at same distance to eyes as to posterior margin of head. Antennal tubercles slightly divergent. Mid-ventral region of head glabrous.

Antenna. With abundant short decumbent setae. Scapus surpassing apex of head in half its length. Scapus dark brown, pedicellus and basiflagellomere light brown darkened distally, distiflagellomere brown with a subbasal yellowish band. Scapus thick, pedicellus and basiflagellomere thickened distally, distiflagellomere fusiform.

Rostrum. Surpassing procoxae, not reaching mesocoxae. Light brown, article IV darker apically; with scarce erect setae, longer ventrally.

Thorax. Collar slightly tapering cephalad ventrally (condition similar to Heraeus Stål). Pronotum pruinose with short decumbent setae. Anterior pronotal lobe black, posterior pronotal lobe reddish brown darker medially. Punctate, more conspicuous on posterior pronotal lobe. Humeral angles protruded. Pleura black, setose and pruinose, punctate.

Scutellum. With a small blunt elevation medially. Dark brown, paler apically, with short semierect setae, punctate, posterior punctures larger.

Hemelytra. Brown, pruinose, with setae. Corium brown darker apically with pale maculae as seen in Figure 1. Clavus brown with five rows of punctures. Mem-

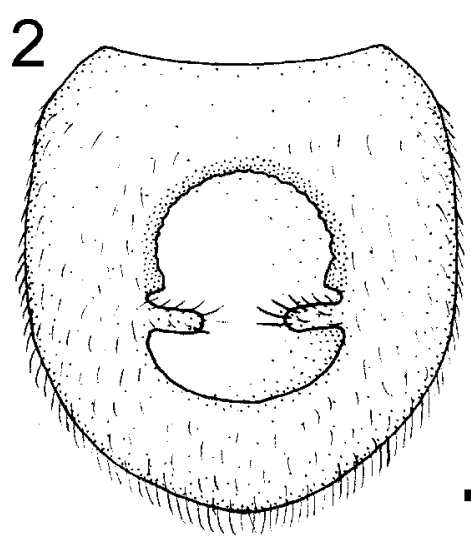

4

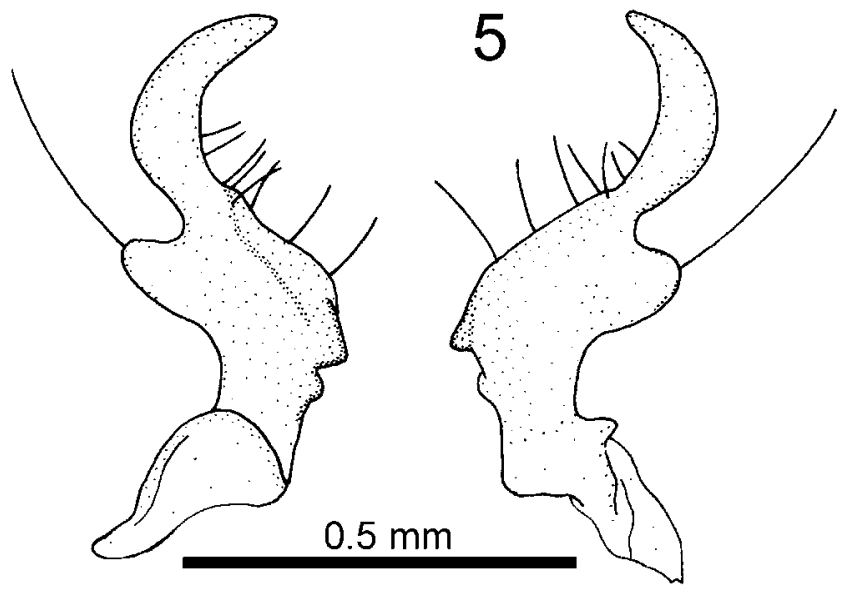

3

\section{$0.5 \mathrm{~mm}$}

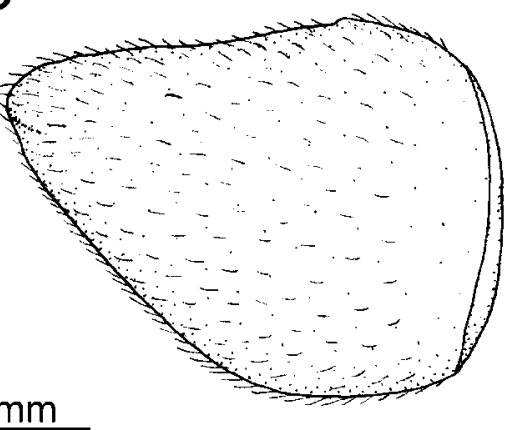

$0.5 \mathrm{~mm}$
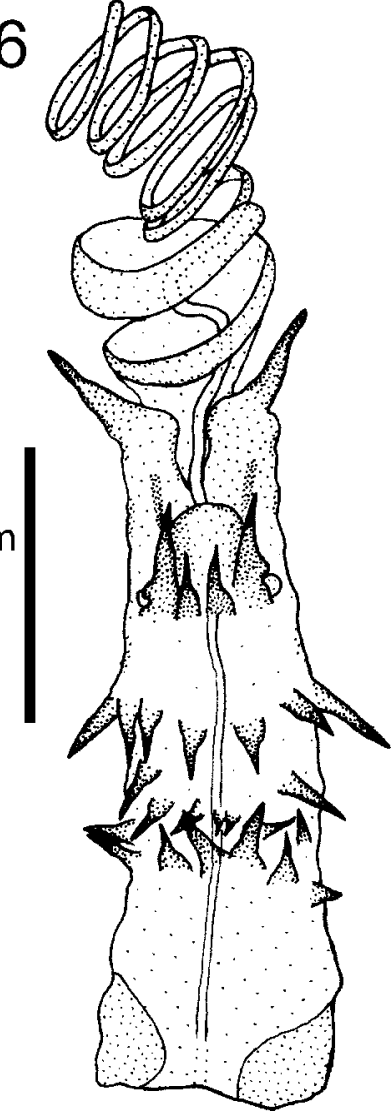

Figures 2-6. Catenes australis sp. n. 2, 3. Pygophore: 2. dorsal view, 3. lateral view; 4, 5. Right paramere: 4. inner view, 5. outer view; $\mathbf{6}$. Aedeagus, anterior view. 
brane brown with an apical whitish maculae, veins irregularly paler.

Legs. With erect setae longer on profemora. Coxae caramel brown, femora light brown spotted with brown more conspicuous on profemora; meso and metafemora with a subapical brown band and brown apex. Tibiae light brown darker distally; meso- and metatibiae with a subbasal brown band. Tarsi light brown, tarsi I distally and pretarsi darker. Procoxae with a spine, protrochanters unarmed. Profemora with two rows of spines on basal half; inner row with three large spines and four minute ones, outer row with two large spines, with a field of minute spines between both rows. Protibiae with abundant minute spines on inner surface, mesoand metatibiae with spiniform setae.

Abdomen. Black brownish distally, with abundant short decumbent setae.
Male genitalia. Pygophore: anterior margin of dorsal aperture rounded with small denticles, adjacent area strongly sclerotized; inner projections long and digitiform (Fig. 2); in lateral view, dorsal margin horizontal (Fig. 3).

Paramere. (Figs 4-5). Large, blade broad and curved, outer projection blunt bearing a long setae, inner projection with two tubercles.

Aedeagus (Fig. 6). Conjunctiva with the basal third sclerotized, with large spines arranged in four rows anteriorly and two pairs posteriorly, vesica with two sclerotized lobes ending in a stout spine, processus gonopori thin and long.

Paratypes. Females similar to males in all respects. In some specimens the large proximal spine on inner row of profemora is absent, it can even be absent in only one of the profemora.

\section{Key to the species of Catenes}

1. Total length less that $7 \mathrm{~mm}$. Distal third of meso- and metafemora strongly contrastingly dark brown; meso- and metatibia uniformly coloured. C. spiculus Slater \& Baranowski

- Total length over $7.9 \mathrm{~mm}$. Darkened distal third of meso- and metafemora interrupted by a pale yellow annulus; apices of all tibiae

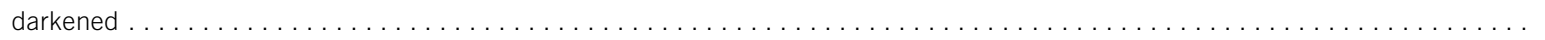

2. Scapus dark, surpassing about $1 / 2$ apex of head; rostrum short, slightly surpassing procoxae; hemelytron brown, with a small subapical corial macula and a paler apical macula on membrane. . .

- Scapus yellow, about reaching apex of head; rostrum long, slightly surpassing metacoxae; different colouration pattern on hemelytron, veins of membrane paler. C. porrectus Distant

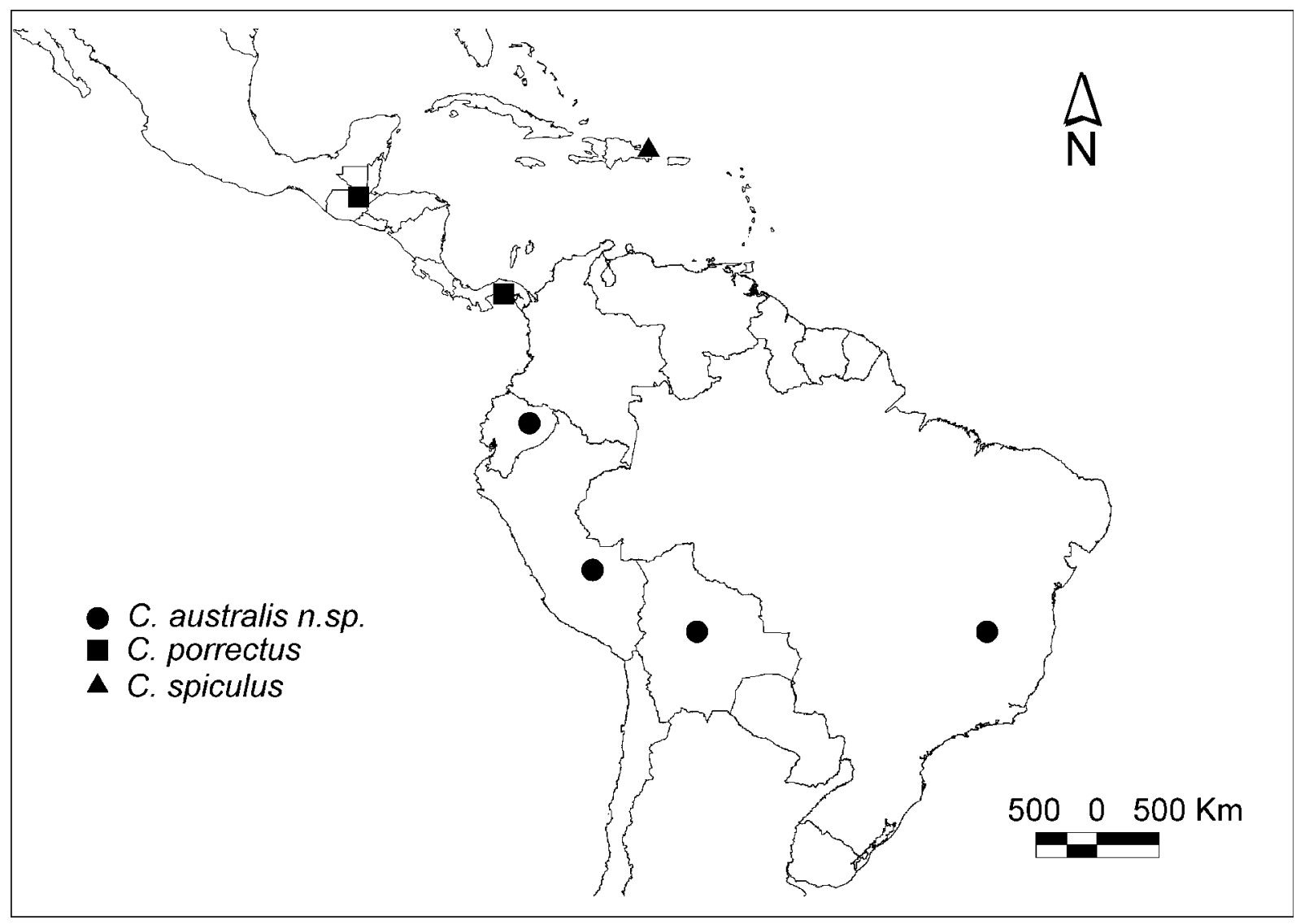

Figure 7. Geographic distribution of genus Catenes sp. 
Table 1. Measurements (mm) of type series of Catenes australis sp. $\mathrm{n}$.

\begin{tabular}{|c|c|c|c|c|c|c|}
\hline & Holotype & Paratype Male & Paratype Male & Paratype Male & Paratype Female & Paratype Female \\
\hline Total length & 9.33 & 9.60 & 9.06 & 9.73 & 9.46 & 8.66 \\
\hline Head Length & 1.89 & 1.89 & 1.82 & 1.79 & 1.86 & 1.82 \\
\hline Head width & 1.15 & 1.18 & 1.15 & 1.20 & 1.22 & 1.14 \\
\hline Anteocular length & 0.83 & 0.80 & 0.83 & 0.80 & 0.77 & 0.80 \\
\hline Interocular length & 0.56 & 0.56 & 0.56 & 0.59 & 0.58 & 0.56 \\
\hline Interocellar length & 0.35 & 0.32 & 0.34 & 0.35 & 0.37 & 0.34 \\
\hline Postocular length & 0.48 & 0.48 & 0.48 & 0.48 & 0.48 & 0.45 \\
\hline Rostral article I & 0.96 & 0.96 & 0.91 & 0.96 & 0.93 & 0.96 \\
\hline Rostral article II & 0.96 & 1.04 & 0.93 & 1.04 & 1.04 & 1.04 \\
\hline Rostral article III & 0.67 & 0.67 & 0.64 & 0.67 & 0.67 & 0.67 \\
\hline Rostral article IV & 0.43 & 0.48 & 0.43 & 0.45 & 0.45 & 0.46 \\
\hline Scapus & 0.80 & 0.77 & 0.74 & 0.77 & 0.70 & 0.70 \\
\hline Pedicellus & 1.98 & 1.98 & 1.95 & 2.14 & 1.82 & 1.89 \\
\hline Basiflagellomere & 1.82 & 1.82 & 1.82 & 1.95 & 1.73 & 1.76 \\
\hline Distiflagellomere & 1.73 & 1.70 & 1.73 & 1.86 & 1.60 & 1.66 \\
\hline Collar length & 0.16 & 0.13 & 0.13 & 0.19 & 0.19 & 0.19 \\
\hline APL length & 0.74 & 0.77 & 0.74 & 0.74 & 0.74 & 0.70 \\
\hline PPL length & 0.90 & 0.90 & 0.83 & 0.90 & 0.90 & 0.90 \\
\hline Collar width & 0.80 & 0.82 & 0.77 & 0.85 & 0.85 & 0.80 \\
\hline APL width & 1.36 & 1.36 & 1.31 & 1.36 & 1.39 & 1.36 \\
\hline PPL width & 2.21 & 2.14 & 2.08 & 2.21 & 2.37 & 2.14 \\
\hline Abdominal length & 4.20 & 4.33 & 4.20 & 4.40 & 4.40 & 3.86 \\
\hline
\end{tabular}

Remarks. Until now the genus Catenes was known only from Central America (C. spiculus from Dominican Republic, and C. porrectus from Guatemala, and Panama); the new species extends the geographic distribution of this genus to South America (Bolivia, Brazil, Ecuador, and Peru) (Fig. 7).

The phallus of Catenes australis shows large spines on conjunctiva and two lobes on vesica. This condition would take the genus Catenes out of the group of the long-legged rapid running forms including Myodocha Latreille, Heraeus Stål and Orthaea Dallas, which show a phallus unarmed or with minute spines as some species of the genus Heraeus. After this, the phylogenetic relationships of the genus Catenes remain uncertain.

\section{Acknowledgments}

This work was funded by the Consejo Nacional de Investigaciones Científicas y Técnicas, Argentina.

\section{References}

Distant, W. L. 1882-1893. Insecta. Rhynchota. Hemiptera-Heteroptera. Vol I. Biologia Centrali-Americana. London (v)xx + 462 pp. (Lygaeidae 1882: 173-220 \& 1893 Suppl.: 378472).

Slater, J. A. \& Baranowski, R. M. 1994. Three new species of rhyparochromine Lygaeidae (Hemiptera: Heteroptera) from Hispaniola. - Florida Entomologist 77 (4): 488-494. 